\section{PENGANTAR \\ STATISTIKA TERAPAN}

Penulisan buku ini didasari oleh pengalaman empiris penulis, sehingga buku ini disusun dari berbagai referensi buku statistika dan pengalaman mengajar penulis saat mengampu mata kuliah Statistika di Fakultas Keguruan dan IImu Pendidikan. Mahasiswa sering mengalami kesulitan untuk memahami buku-buku teks statistika yang telah ada. Oleh karena itu, buku Pengantar Statistika Terapan ini disajikan secara terstruktur, mulai dari uraian konsep, contoh soal, latihan soal yang dilengkapi dengan solusi, serta tutorial aplikasi SPSS untuk menganalisis secara deskriptif maupun inferensial.

Buku ini merupakan terobosan bagi para pemula yang ingin menekuni dunia statistika. Sebagaimana diketahui yang selama ini menjadi ganjalan para mahasiswa dalam memahami statistika adalah bagaimana memahami statistika deskriptif maupun statistika inferensial menggunakan bahasa yang sederhana. Buku ini hadir untuk menjadi pengantar sekaligus panduan bagi penggunanya yang setiap langkahnya mudah diikuti, penggunaan bahasa yang sederhana, serta dilengkapi dengan contoh permasalahan yang lengkap dengan solusinya. Semoga buku ini dapat bermanfaat bagi pembacanya sehingga dapat menjadi modal awal untuk mengembangkan kemampuan statistika dengan cara mengeksplor kajian dengan lebih mendalam.
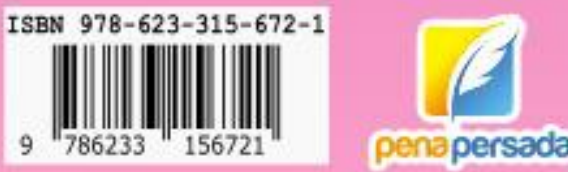

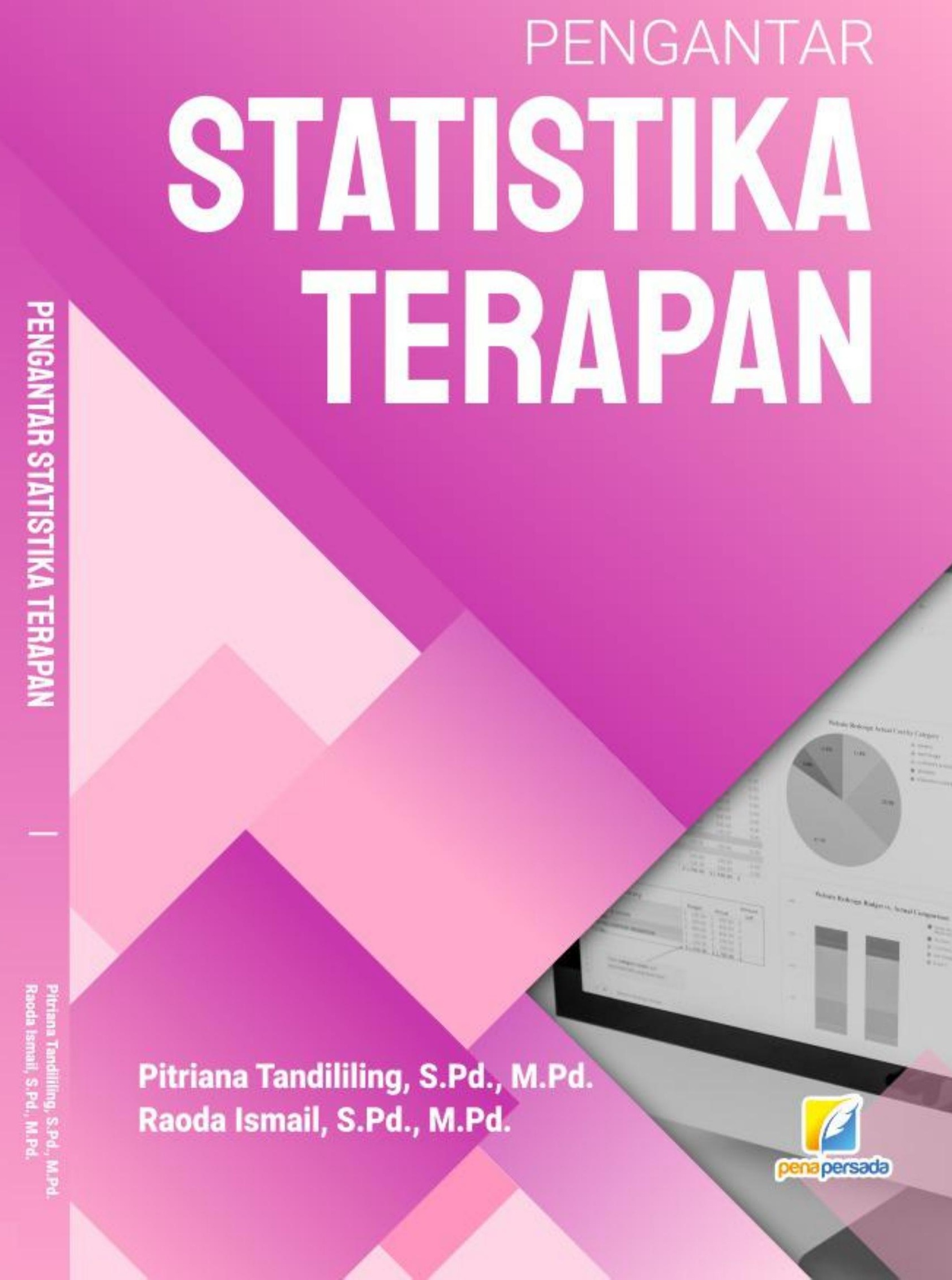




\section{Pengantar Statistika Terapan}

Pitriana Tandililing, S.Pd., M.Pd.

Raoda Ismail, S.Pd., M.Pd.

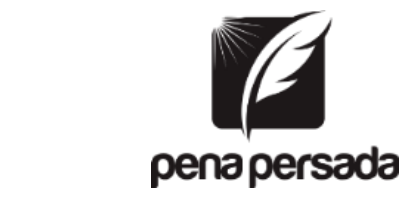

PENERBIT CV. PENA PERSADA 


\section{Pengantar Statistika Terapan}

\section{Penulis:}

Pitriana Tandililing, S.Pd., M.Pd.

Raoda Ismail, S.Pd., M.Pd.

ISBN : 978-623-315-672-1

\section{Design Cover :}

Retnani Nur Briliant

Layout :

Eka Safitry

\section{Penerbit CV. Pena Persada}

Redaksi :

Jl. Gerilya No. 292 Purwokerto Selatan, Kab. Banyumas

Jawa Tengah

Email : penerbit.penapersada@gmail.com

Website : penapersada.com Phone : (0281) 7771388

Anggota IKAPI

All right reserved

Cetakan pertama : 2021

Hak Cipta dilindungi oleh undang-undang. Dilarang memperbanyak karya tulis ini dalam bentuk apapun tanpa izin penerbit 


\section{Kata Pengantar}

Puji dan syukur penulis panjatkan kehadirat Tuhan Yang Maha Kuasa, karena atas limpahan rahmat dan inayah-Nya, sehingga penulis dapat menyelesaikan buku Pengantar Statistika Terapan ini. Buku ini merupakan hasil refleksi dan internalisasi diskusi ilmiah dalam perkuliahan, kegiatan penelitian, dan pelatihan statistika. Statistika mempunyai peran penting dalam pengembangan penelitian, terutama dalam penelitian kuantitatif.

Pengetahuan terkait statistika yang dimiliki oleh penulis tidak terlepas dari ikhtiar menuntut ilmu selama menempuh pendidikan. Oleh karena itu, penulis mengucapkan terima kasih kepada semua pihak, terutama rekan-rekan dosen dan mahasiswa yang telah memberikan masukan yang membangun baik dalam diskusi ilmiah maupun dalam interaksi selama perkuliahan berlangsung.

Dalam penulisan dan penyuntingan buku ini, penulis menyadari bahwa isi dari buku ini masih terdapat kekurangan, oleh karena itu penulis meminta saran dan kritik yang membangun demi penyempurnaan buku ini. Semoga buku ini dapat memberikan manfaat literasi bagi pembaca, khususnya mahasiswa dan atau peneliti dalam rangka melaksanakan analisis data penelitian untuk menjawab permasalahan-permasalahan pendidikan serta mengembangkan kompetensi penerus bangsa dalam melakukan perubahan ke arah yang lebih baik.

Jayapura, Agustus 2021

Tim Penulis 


\section{DAFTAR ISI}

Kata Pengantar ...................................................................ii

DAFTAR ISI.........................................................................

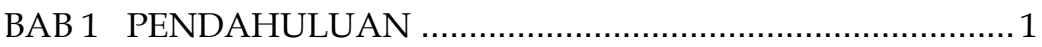

A. Pengertian Statistika .............................................. 1

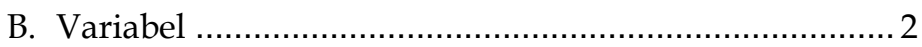

C. Pengukuran dan Skala Pengukuran ............................... 3

BAB 2 PENGUMPULAN DAN PENYAJIAN DATA ……............. 5

A. Pengumpulan Data .................................................... 5

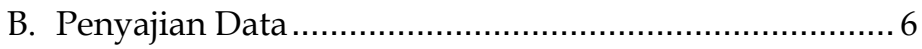

1. Tabel Distribusi Frekuensi.......................................... 6

2. Grafik dan Diagram............................................. 10

BAB 3 UKURAN KECENDERUNGAN MEMUSAT DAN

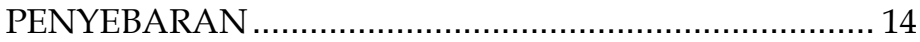

A. Ukuran Kecenderungan Memusat .............................. 15

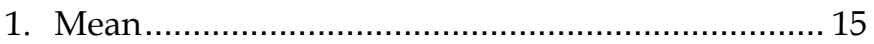

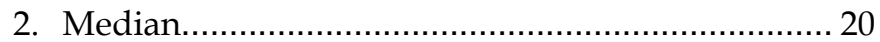



4. Quartil ................................................................ 34

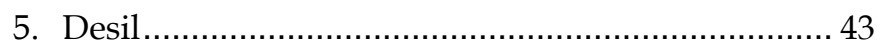

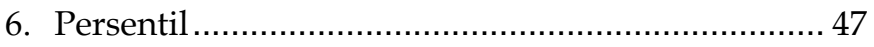

B. Ukuran Penyebaran.................................................... 59

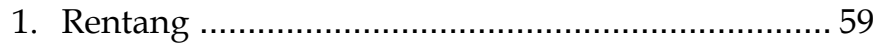

2. Rentang AntarQuaril ............................................. 63

3. Standar Deviasi atau Simpangan Baku .................. 75

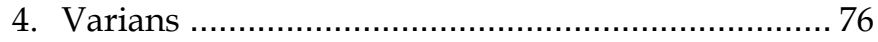

5. Koefisien Varians.................................................. 78 
6. Koefisien Kemiringan dan Koefisien Kurtosis ......104

BAB 4 PENGANTAR TEORI PELUANG …………..................123

A. Prinsip Dasar Mencacah .............................................123

1. Aturan Perkalian ................................................123

2. Aturan Penjumlahan ...........................................124

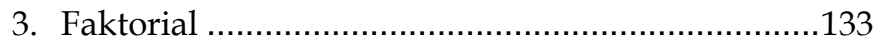

4. Permutasi ......................................................135

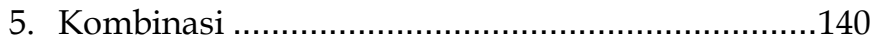

B. Konsep Dasar Peluang …........................................149



2. Ruang Sampel dan Titik Sampel ...........................149

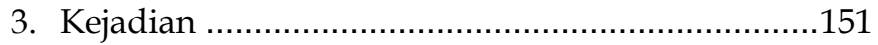

4. Hubungan Antar Kejadian ....................................156

5. Definisi Peluang …............................................162

6. Aljabar Peluang ...................................................168

7. Kaidah Total Peluang Dan Kaidah Bayes...............184

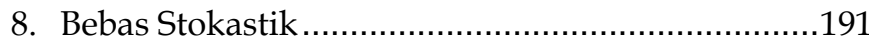

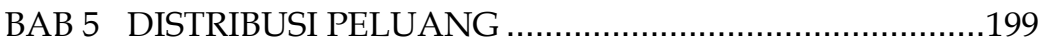

A. Peubah Acak .............................................................199

1. Pengertian Peubah Acak .......................................199

2. Jenis-jenis Peubah Acak .......................................199

B. Distribusi Peluang Gabungan ...................................208

C. Fungsi Densitas Gabungan.........................................220

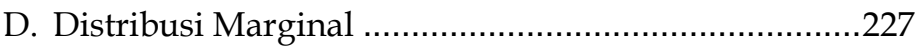



F. Momen dan Pembangkit Momen ...............................263

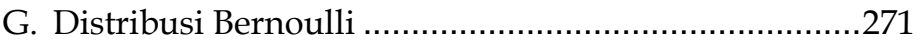


H. Distribusi Binomial ...................................... 274

I. Distribusi Normal ......................................... 280

J. Distribusi Chi Kuadrat ..................................... 286

K. Distribusi T (Distribusi Student) .......................... 292

L. Distribusi F ............................................... 300

BAB 6 PENGOLAHAN DATA MENGGUNAKAN SPSS 20 .... 305

A. Praktikum 1 : Input Data ................................ 305

B. Praktikum 2 : Penyajian Data dan Pengolahan Data. 315

C. Praktikum 3 : Statistika Inferensi......................... 329

Daftar Pustaka ........................................................... 341 


\section{BAB 1 \\ PENDAHULUAN}

\section{A. Pengertian Statistika}

Statistik berasal dari bahasa Yunani yaitu status yang dalam bahasa Inggris disebut state yang berarti negara. Hal ini diterjemahkan secara holistik sebagai bidang-bidang kehidupan dari suatu negara. Bidang-bidang ini dibagi menjadi partisi-partisi yang lebih spesifik seperti data atau kondisi tentang suatu bidang. Contohnya dalam bidang pendidikan, terdapat data terkait guru, jumlah guru, jenjang pendidikan guru, golongan dan pangkat guru, sertifikasi guru, masa kerja guru, bidang keahlian guru, sampai pada sistem honorarium guru.

Statistik sering disamakan dengan statistika. Berdasarkan penjabaran di atas, terlihat bahwa statistik diterjemahkan sebagai keadaan sesuatu, misalnya statistik guru, statistik pendidikan, dan statistik pengangguran. Sehingga, pada dasarnya statistik menerjemahkan fakta dan deskripsi yang dikuantitatifkan menjadi angka-angka atau nilai. Data yang diterjemahkan oleh statistik bersifat informatif, komunikatif, dan praktis. Sehingga tampilan informasi yang disajikan tersebut harus berbentuk gambaran atau ringkasan data yang sederhana (Kadir, 2015).

Berbeda dengan statistik, statistika adalah metode untuk mengumpukan, mengolah, menganalisis dan menyajikan data serta menarik kesimpulan berdasarkan hasil analisis data tersebut. Statistika merupakan ilmu yang mempelajari prosedur-prosedur yang digunakan dalam pengumpulan, penyajian, analisis, dan interpretasi data. Secara umum, statistika dapat dikategorikan berdasarkan asumsi distribusi, jumlah peubah terikat, orientasi pembahasan, dan tujuan dari analisis. 


\section{B. Variabel}

Variabel adalah konsep yang mempunyai nilai yang berubah-ubah atau mempunyai variasi nilai, keadaan, kategori, dan kondisi (Kadir, 2015). Variabel yang didefinisikan secara konseptual dan operasional dapat diterjemahkan sebagai proses penentuan ilmiah yang didasarkan pada kajian teori. Definisi konseptual merupakan pendeskripsian secara abstrak dari suatu variabel, sedangkan definisi operasional merupakan penjelasan secara terperinsi, spesifik, dan jelas dari suatu variabel.

Variabel dapat dikategorikan berdasarkan jenis data dan fungsinya dalam penelitian (Kadir, 2015). Berdasarkan jenis data, variabel terdiri dari variabel diskrit dan kontinu, sedangkan berdasarkan fungsinya, variabel terdiri dari variabel bebas, terikat, dan kontrol.

Berdasarkan jenis data, variabel terdiri dari variabel diskrit dan kontinu. Variabel diskrit adalah variabel yang nilainya terputus. Nilai pada variabel diskrit diperoleh melalui proses membilang. Contohnya jumlah mobil, jumlah tv, jumlah anak, jumlah pegawai dan lain sebagainya. Sedangkan variabel kontinu adalah variabel yang nilainya dapat dinyatakan dalam bentuk pecahan. Pada variabel ini berlaku postuat bilangan rasional, yang berarti di antara dua bilangan rasional terdapat tak hingga banyaknya bilangan rasional lainnya. Contohnya berat badan, luas daerah, jarak rumah, dan lain sebagainya.

Berdasarkan fungsinya, variabel terdiri dari variabel bebas, terikat, kontrol, dan pengikut. Variabel bebas adalah variabel yang memengaruhi variabel lain, biasa juga disebut dengan variabel independen, stimulus, atau prediktor. Variabel terikat adalah variabel yang dipengaruhi oleh variabel lain, biasa juga disebut sebagai variabel tak bebas, dependen, respons, atau kriteria. Contohnya kepercayaan diri yang mempengaruhi kemampuan presentasi seseorang. Jadi kepercayaan diri adalah variabel bebas, dan kemampuan presentasi adalah variabel terikat atau tak bebas. Variabel 
kontrol adalah variabel yang ikut memengaruhi variabel terikat dan pengaruhnya dapat dikontrol. Contohnya, jika hasil analisis data menunjukkan adanya hubungan positif antara model pembelajaran yang digunakan dengan prestasi siswa di sekolah, maka dapat disimpulkan bahwa model pembelajaran berpengaruh terhadap prestasi belajar siswa, padahal diketahui pula bahwa variabel IQ juga berpengaruh terhadap prestasi. Sehingga, variabel IQ sebaiknya dikontrol, maka dalam hal ini IQ dianggap sebagai variabel kontrol.

\section{Pengukuran dan Skala Pengukuran}

Pengukuran merupakan suatu kegiatan awal yang penting dalam analisa statistika. Pengukuran yang dilakukan terhadap variabel dapat didefinisikan sebagai ragam nilai atau taraf ukuran dari variabel yang diukur. Ragam nilai suatu variabel dapat diperoleh melalui pengamatan yang dilakukan terhadap subjek berdasarkan indikator dari satuan tersebut. Hasil dari pengukuran merepresentasikan data yang akan diolah menggunakan teknik analisis tertentu. Oleh karena itu, pengukuran adalah suatu proses untuk memberikan data dari suatu objek dengan menggunakan satuan ukuran tertentu.

Satuan pengukuran biasa disebut dengan skala pengukuran. Skala menentukan statistika uji yang seharusnya digunakan. Pada dasarnya, skala terdiri dari empat jenis yaitu skala nominal, ordinal, interval, dan rasio. Keempat skala tersebut dijelaskan sebagai berikut:

1. Skala Nominal

Skala nominal adalah pengkategorisasian, kejadian atau fenomena ke dalam kategori sehingga yang masuk pada suatu kategori adalah sama dalam hal sifat maupun atribut. Kategori tersebut hanya untuk membedakan antara suatu kejadian dengan kejadian lainnya. Perbedaan yang ada pada skala nominal bersifat kualitatif. Skala ini merupakan lambang kategori yang artinya angka tidak mempunyai arti pada skala ini, dan tidak ada penataan 
antarkategori. Sebagai contoh skala nominal adalah jenis kelamin, jenis pekerjaan, dan sejenisnya.

2. Skala Ordinal

Skala ordinal adalah skala yang angkanya berfungsi menunjukkan adanya ranking atau perjenjangan. Adanya perbedaan angka yang dimiliki oleh objek tidak menunjukkan adanya berbedaan kuantitatif melainkan perbedaan jenjang kualitatif. Skala ini merupakan lambang kategori yang artinya angka tidak mempunyai arti pada skala ini, dan sudah ada penataan antarkategori. Sebagai contoh skala ordinal yaitu tingkat pendidikan SD, SMP, SMA, dan sejenisnya.

3. Skala Interval

Skala interval adalah hasil pengukuran yang memiliki jarak antar jenjang yang selalu sama. Skala ini tidak mempunyai nilai nol mutlak. Perbedaan angka pada skala interval telah memiliki perbedaan kualitatif dan kuantitatif. Angka mempunyai arti pada skala ini. Sebagai contoh skala interval yaitu angka pada suhu, kinerja, indeks prestasi, IQ, dan sejenisnya.

4. Skala Rasio

Skala rasio adalah hasil pengukuran level interval yang memiliki harga nol mutlak, artinya nilai nol pada skala rasio menunjukkan bahwa atribut yang diukur sama sekali tidak ada pada objek yang bersangkutan. Jika hasil pengukuran menunjukkan angka nol, maka berarti benda tersebut benar-benar tidak memiliki karakteristik yang dimaksud. Angka mempunyai arti pada skala in. Sebagai contoh skala rasio adalah berat badan, tinggi badan, waktu, volume, kecepatan, dan sejenisnya. 


\section{BAB 2 \\ PENGUMPULAN DAN PENYAJIAN DATA}

\section{A. Pengumpulan Data}

Pengumpulan data adalah mencatat kejadian, karakteristik, elemen, atau nilai dari suatu variabel. Pencatatan ini akan menghasilkan data mentah yang mempunyai manfaat yang masih terbatas. Agar data lebih berguna, maka data tersebut harus diolah terlebih dahulu, disarikan dan disederhanakan serta dianalisis untuk memperoleh makna dari data tersebut. Tujuan dari pengumpulan data adalah untuk mengetahui suatu masalah dari suatu variabel penelitian.

Dalam pengumpulan data, selain menggunakan teknik pengumpulan data menggunakan tes, dapat juga menggunakan teknik pengumpulan data non-tes. Instrumen dari teknik pengumpulan data tes dapat berupa tes objektif dan subjektif, sedangkan untuk instrumen dari teknik pengumpulan data non-tes dapat berupa dokumentasi, angket, wawancara, dan observasi.

Instrumen yang digunakan untuk mengumpulkan data harus memenuhi kriteria instrumen yang valid dan reliabel. Kriteria instrumen ini dapat diketahui melalui proses validasi teoretis dan empirisnya. Validasi teoretis menyangkut dengan ketepatan instrumen untuk mengukur apa yang hendak diukurnya yang ditinjau dari aspek konten atau isi dari intrumen variabel yang dimaksud. Validasi empiris menyangkut pada ketepatan suatu instrumen berkenaan dengan sekelompok responden yang menjadi sampel uji coba instrumen. Selanjutnya analisis data intrumen hasil uji coba bertujuan untuk melihat kualitas instrumen dari aspek validitas, reliabilitas, tingkat kesukaran, dan daya pembedanya. 
Selanjutnya dilakukan pengolahan data terkait data hasil uji coba instrumen. Dalam proses mengolah data tersebut, dilakukan pengelompokan dan membuat ringkasan data berdasarkan data mentah hasil dari pengumpulan data dengan menggunakan rumus tertentu sesuai dengan kebutuhan. Misalnya menghitung jumlah, rata-rata, median, modus, dan lain sebagainya. Skor mentah dapat diolah menjadi nilai dalam berbagai kategori. Hasil pengolahan data dapat disajikan dalam bentuk tabel, grafik, dan diagram sesuai dengan tujuan dari penyajian data.

\section{B. Penyajian Data}

Penyajian data dapat dalam bentuk tabel, grafik dan diagram. Penyajian data dalam bentuk tabel dapat berupa tabel distribusi frekuensi relatif dan kumulatif, sedangkan penyajian data dalam bentuk grafik dapat berupa histogram dan poligon frekuensi, ogive, diagram batang, diagram garis, diagram lingkaran, atau diagram dahan.

\section{Tabel Distribusi Frekuensi}

Tabel distribusi frekuensi adalah cara menyajikan data berdasarkan pengelompokan data dalam kategori atau kelas interval dengan adanya frekuensi tertentu. Tujuan penyajian data menggunakan tabel distribusi frekuensi adaah untuk memudahkan pembaca dalam menginterpretasi dan mengomunikasikan sekumpulan data uamh lebih besar. Data dapat diurutkan dari data terkecil ke data terbesar maupun sebaliknya untuk mengelompokkan data berfrekuensi.

Penyajian data dengan menggunakan tabel distribusi frekuensi dapat dijelaskan melalui contoh berikut. 
Contoh:

Berikut ini diberikan data megenai hasil tes kemampuan spasial dari 40 mahasiswa:

$\begin{array}{llllllllll}65 & 72 & 67 & 82 & 72 & 91 & 67 & 73 & 71 & 70\end{array}$

$\begin{array}{llllllllll}85 & 87 & 68 & 86 & 83 & 90 & 74 & 89 & 75 & 61\end{array}$

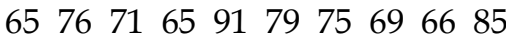

$957473 \quad 68 \quad 869070718868$

Untuk memperoleh deskriosi dari sebaran data di atas maka skor-skor tersebut dapat disajikan menjadi lebih sederhana dengan tabel distribusi frekuensi dengan langkah-langkah sebagai berikut:

a. Mengurutkan data dari skor terendah hingga skor tertinggi.

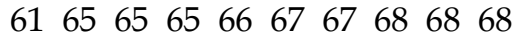

69707071717172727373

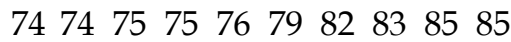

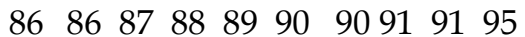

b. Menentukan rentang atau range $(\mathrm{R})$ yaitu selisi skor tertinggi dan skor terendah atau $R=95-61=34$

c. Menentukan banyaknya kelas interval, yaitu paling sedikit 5 kelas dan paling banyak 15 kelas atau dapat juga menggunakan aturan sturgess dengan rumus : banyak kelas $(\mathrm{BK})=1+3,3 \log \mathrm{n}$, di mana $\mathrm{n}$ menyatakan banyaknya data untuk contoh di atas banyaknya data adalah 40 atau $n=40$ dengan demikian $B K=1+$ $3,3 \log 40=1+3,3(1,6021)=6,28693$. Banyak data diperoleh melalui proses membilang maka ada dua kemungkinan yaitu $(B K)=6$ atau $(B K)=7$. Di sini akan diambil banyak kelas sebanyak 7 buah

d. Panjang kelas $(p)=\frac{\operatorname{Rentang}(R)}{B K}$, misalkan dipilih $(B K)=7$ maka panjang kelas $(p)=\frac{34}{7}=4,86 \approx 5$. Karena datanya dicatat dalam bilangan bulat, maka panjang kelasnya diambil 5.

e. Menetapkan data pertama dengan cara menggunakan data terkecil sebagai data batas bawah kelas interval pertama atau data yang lebih kecil dari data terkecil 
tetapi selisinya tidak melebihi dari setengah dari panjang kelas. Misalnya kita ambil $(61-65)$.

f. Menyusun kelas interval dalam tabel distribusi frekuensi, sebagai berikut.

\begin{tabular}{|c|c|c|}
\hline Skor & Turus & Frekuensi \\
\hline $61-65$ & $/ / / /$ & 4 \\
\hline $66-70$ & $/ / / / / /$ & 9 \\
\hline $71-75$ & $/ \Upsilon / / / X /$ & 11 \\
\hline $76-80$ & $/ /$ & 2 \\
\hline $81-85$ & $/ / /$ & 4 \\
\hline $86-90$ & $/ \Upsilon / / / /$ & 7 \\
\hline $91-95$ & $/ / /$ & 3 \\
\hline Jumlah & & 40 \\
\hline
\end{tabular}

Tabel distribusi frekuensi dapat disusun menjadi bentuk distribusi frekuensi relatif dan kumulatif.

\section{a. Tabel Distribusi Frekuensi Relatif}

Tabel distribusi frekuensi dapat disajikan dalam bentuk frekuensi relatif $f(\%)$. Penghitungan frekuensi relatif dapat menggunakan rumus atau fungsi sebagai berikut:

$f(\%)=\frac{\text { frekuensi absolut }}{n} \times 100 \%$

Dengan menerapkan rumus tersebut, maka akan diperoleh tabel distribusi frekuensi relatif sebagai berikut: 


\begin{tabular}{|c|c|c|c|}
\hline Skor & Turus & $\begin{array}{c}\text { Frekuensi } \\
\text { Absolut }\end{array}$ & $\begin{array}{c}\text { Frekuensi } \\
\text { Relatif (\%) }\end{array}$ \\
\hline $61-65$ & $/ / / /$ & 4 & 10 \\
\hline $66-70$ & $\begin{array}{c}\text { / } / / / \\
/ / /\end{array}$ & 9 & 22,5 \\
\hline $71-75$ & $\begin{array}{c}\text { /X/ } \\
\text { /X/ / }\end{array}$ & 11 & 27,5 \\
\hline $76-80$ & $/ /$ & 2 & 5 \\
\hline $81-85$ & $/ / / /$ & 4 & 10 \\
\hline $86-90$ & $/$ N// & 7 & 17,5 \\
\hline $91-95$ & $/ / /$ & 3 & 7,5 \\
\hline Jumlah & & 40 & 100 \\
\hline
\end{tabular}

\section{b. Tabel Distribusi Frekuensi Kumulatif}

Tabel distribusi frekuensi kumulatif adalah tabel distribusi frekuensi yang menjumlahkan semua frekuensi pada setiap kelas interval. Frekuensi kumulatif disimbolkan dengan $f$ kum. Frekuensi kumulatif dapat dibedakan menjadi frekuensi kumulatif kurang dari dan frekuensi kumulatif sama atau lebih.

\begin{tabular}{|c|c|}
\hline Skor & Frekuensi kumulatif \\
\hline Kurang dari 65 & 1 \\
\hline Kurang dari 70 & 11 \\
\hline Kurang dari 75 & 22 \\
\hline Kurang dari 80 & 26 \\
\hline Kurang dari 85 & 28 \\
\hline Kurang dari 90 & 35 \\
\hline Kurang dari 95 & 40 \\
\hline
\end{tabular}

\begin{tabular}{|l|l|}
\hline Skor & Frekuensi Absolut \\
\hline 61 atau lebih & 40 \\
\hline 66 atau lebih & 36 \\
\hline 71 atau lebih & 27 \\
\hline 76 atau lebih & 16 \\
\hline 81 atau lebih & 14 \\
\hline 86 atau lebih & 10 \\
\hline 91 atau lebih & 3 \\
\hline
\end{tabular}




\section{Grafik dan Diagram}

Pada umumnya, penyajian data dengan menggunakan grafik lebih menarik dibandingkan penyajian data dengan menggunakan tabel. Hal ini dikarenakan penyajian data menggunakan grafik lebih menggambarkan keseluruhan sifat data secara visual. Grafik dan diagram terdiri dari histogram dan poligon frekuensi, ogive, diagram batang, diagram garis, serta diagram lingkaran.

\section{a. Histogram dan Poligon Frekuensi}

Untuk menyajikan data dalam bentuk histogram dan poligon frekuensi dibutuhkan diagram Cartesius. Sumbu mendatar untuk menyarakan kelas interval, sedangkan sumbu tegak untuk menyatakan frekuensi. Diagramnya berbetuk batang-batang yang bersisian.

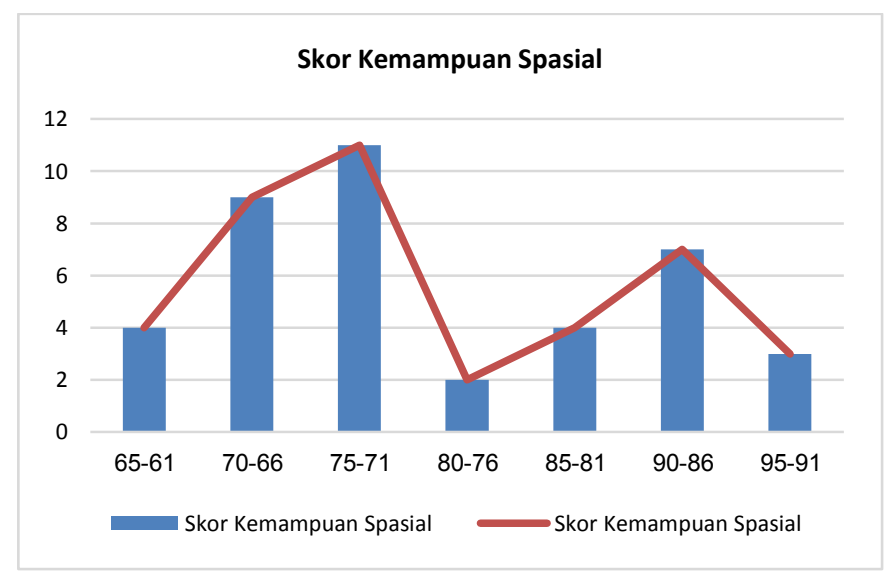

\section{b. Ogive}

Ogive adalah grafik yang menggambarkan distribusi frekuensi kumulatif. Jika pada grafik histogram, sumbu vertikalnya menunjukkan frekuensi dan sumbu horisontalnya menunjukkan nilai, maka demikian pula adanya pada Ogive. Garis pada Ogive menghubungkan frekuensi berturut-turut dari batas 
bawah kelas interval pertama sampai ke frekuensi batas bawah kelas interval terakhir.
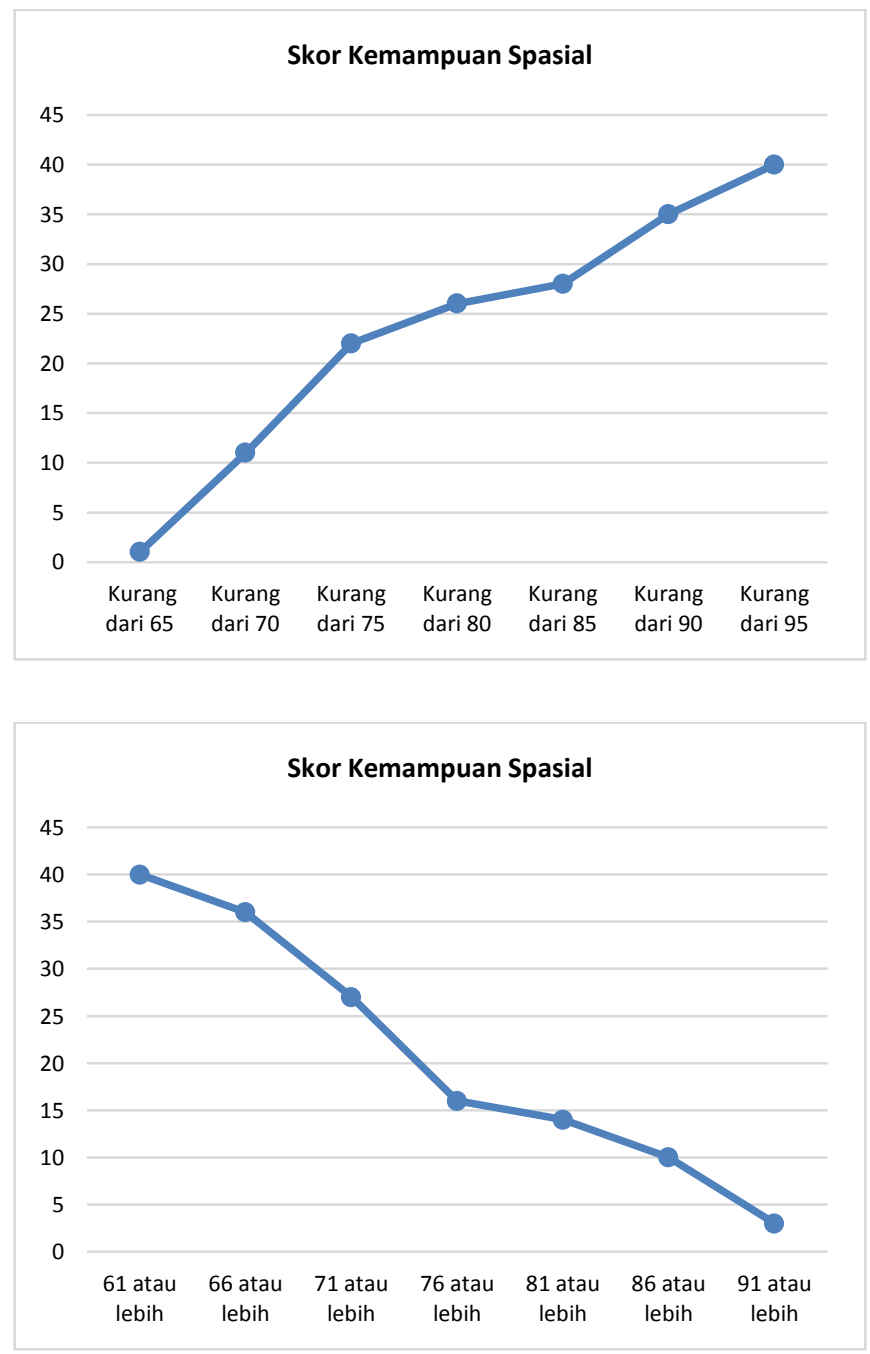

\section{c. Diagram Batang}

Diagram batang adalah diagram yang berbentuk persegi panjang. Batang yang dimaksud menunjukkan frekuensi yang dibuat terpisah antara satu dengan yang lainnya. Setiap batang memiliki lebar yang sama. 
Tinggi batang sebanding dengan frekuensi dari setiap jenis data.

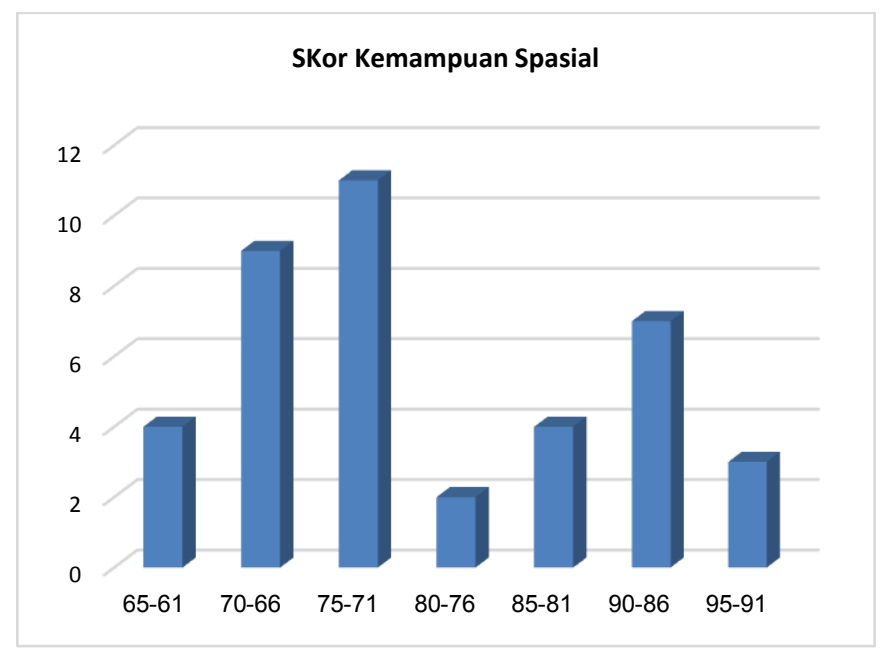

\section{d. Diagram Garis}

Diagram garis adalah diagram yang menggambarkan data yang bersambung atau kontinu. Contoh dari data kontinu adalah luas, kelahiran, suhu tubuh dan lain sebagainya.

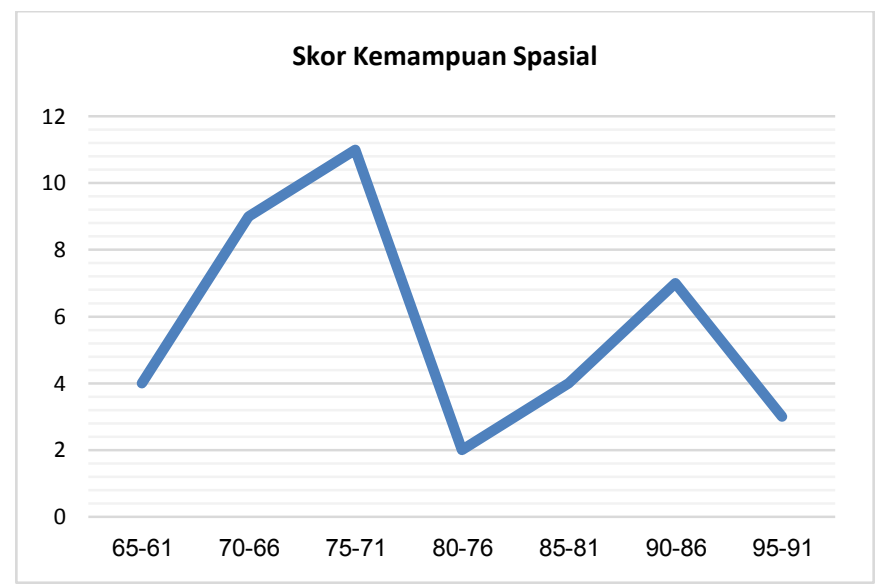


e. Diagram Lingkaran

Diagram lingkaran adalah diagram yang menggambarkan data yang disajikan dalam berntuk lingkaran yang dipartisi menjadi beberapa juring. Sebelum menyajikan data dalam bentuk diagram lingkaran, maka sektor-sektor data terlebih dahulu dibuat ke dalam derajat.

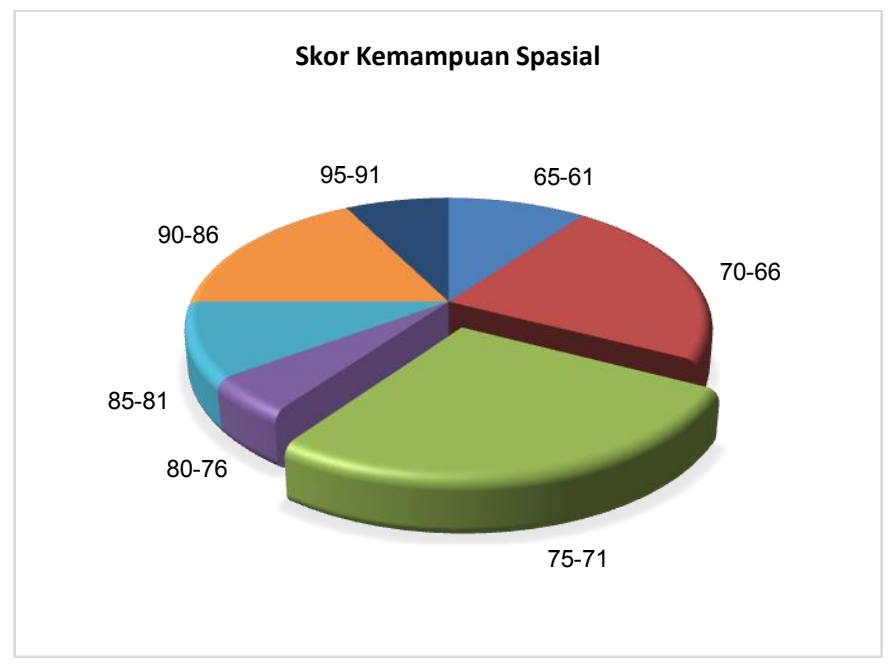

